\title{
Jackfruit seed: an accompaniment to functional foods
}

\author{
Semente de jaca: um acompanhamento para alimentos \\ funcionais
}

\section{Roji Waghmare ${ }^{1}$, Nagma Memon ${ }^{1}$, Yogesh Gat ${ }^{2 *}$ (D), Sukhmani Gandhi², Vikas Kumar², Anil Panghal ${ }^{2}$}

${ }^{1}$ D.Y. Patil University, School of Biotechnology and Bioinformatics, Navi Mumbai - India

${ }^{2}$ Lovely Professional University, Department of Food Technology and Nutrition, Phagwara - India

*Corresponding Author: Yogesh Gat, Lovely Professional University, Department of Food Technology and Nutrition, 144 411, Phagwara - India, e-mail: yogeshcft10@gmail.com

Cite as: Waghmare, R., Memon, N., Gat, Y., Gandhi, S., Kumar, V., \& Panghal, A. (2019). Jackfruit seed: an accompaniment to functional foods. Brazilian Journal of Food Technology, 22, e2018207.

\begin{abstract}
The Jackfruit (Artocarpus heterophyllus) is a well-known fruit in many Asian countries. Jackfruit seeds are underutilized and less acknowledged by people, but they have considerable nutritional benefits and can be considered as a potential functional food ingredient. To the best of the authors' knowledge, a large number of studies have been carried out concerning the composition and health implications of jackfruit seeds. However, in broder manner there is a need to explore the information about the commercial production of jackfruit seeds and their incorporation in food products. Products with incorporated jackfruit seed flour possess better nutraceutical appeal, leading to improved consumer acceptability. The present study attempted to review the health-promoting effects of jackfruit seeds with special emphasis on their applications in the food. It also reveals the valorization of jackfruit seeds in various value-added products along with their effects on the different properties of the products.
\end{abstract}

Keywords: Jackfruit seed flour; Value-added products; Food properties; Waste utilization.

\section{Resumo}

A Jaca (Artocarpus heterophyllus) é uma fruta bem conhecida em muitos países asiáticos. As sementes de jaca são sub-utilizadas e pouco conhecidas pela população, mas elas têm benefícios nutricionais consideráveis e podem ser consideradas como ingredientes potenciais para alimentos funcionais. Segundo o conhecimento dos autores, há um número grande de estudos sobre a composição e as implicações para a saúde das sementes de jaca. Contudo, é preciso explorar a informação sobre a produção comercial das sementes de jaca e a sua incorporação em produtos alimentícios, de uma forma geral. Produtos com a incorporação da farinha da semente de jaca têm maior apelo nutracêutico, levando a uma maior aceitação pelos consumidores. O presente estudo buscou revisar os efeitos promotores de saúde das sementes de jaca, com ênfase especial nas suas aplicações no sistema alimentar. Também revela a valorização das sementes de jaca em vários produtos de valor agregado, junto com seus efeitos nas diferentes propriedades dos produtos.

Palavras-chave: Farinha da semente da jaca; Produtos com valor agregado; Propriedades de alimentos; Utilização de resíduos. 


\section{Introduction}

Jackfruit (Artocarpus heterophyllus), of the Moraceae family, is an enormous edible tree-borne tropical fruit. It is believed to be indigenous to Western Ghats of India but is now most widely cultivated in Bangladesh, Burma, Malaysia, Indonesia, Thailand, and on a smaller scale in Brazil and Australia (Hossain, 2014). Jackfruit is rich in protein, digestible starch, minerals and vitamins. Each $100 \mathrm{~g}$ of ripe flakes contains 287 to $323 \mathrm{mg}$ potassium, 30 to $73 \mathrm{mg}$ calcium and 11 to $19 \mathrm{~g}$ carbohydrates (Prakash et al., 2009). It is an energy-rich fruit suitable for the treatment of physical or mental fatigue, stress and muscle weakness and also for athletes. It has been found to exhibit antimicrobial, anti-diabetic, anti-inflammatory, antioxidant and antihelmintihc properties (Shanmugapriya et al., 2011). It is apparent from the information summarized in Table 1 that jackfruit is the richest source of protein $(1.72 \mathrm{~g})$ when compared to other fruits, followed by banana $(1.09 \mathrm{~g})$, mango $(0.82 \mathrm{~g})$, fig $(0.75 \mathrm{~g})$ and pineapple $(0.54 \mathrm{~g})$. It is also an abundant source of potassium, with $448 \mathrm{mg}$ per $100 \mathrm{~g}$, and provides a plentiful supply of thiamine, niacin, calcium, sodium, magnesium and vitamin $\mathrm{B}_{6}$ (United States Department of Agriculture, 2016).

Table 1. Nutritional profile of various fruits (values per $100 \mathrm{~g}$ ).

\begin{tabular}{|c|c|c|c|c|c|}
\hline Nutrient & Jackfruit & Pineapple & Mango & Banana & Fig \\
\hline Energy (kcal) & 95 & 50 & 60 & 89 & 74 \\
\hline Carbohydrates (g) & 23 & 13 & 15 & 22.84 & 19.18 \\
\hline Sugars $(\mathrm{g})$ & 19.08 & 9.85 & 13.7 & 12.23 & 16.26 \\
\hline Dietary fiber $(\mathrm{g})$ & 1.5 & 1.4 & 1.6 & 2.6 & 2.9 \\
\hline Fat $(g)$ & 0.64 & 0.12 & 0.38 & 0.33 & 0.30 \\
\hline Protein $(\mathrm{g})$ & 1.72 & 0.54 & 0.82 & 1.09 & 0.75 \\
\hline Thiamine (mg) & 0.105 & 0.079 & 0.028 & 0.031 & 0.060 \\
\hline Riboflavin (mg) & 0.055 & 0.032 & 0.038 & 0.073 & 0.050 \\
\hline Niacin (mg) & 0.92 & 0.5 & 0.669 & 0.665 & 0.400 \\
\hline Pantothenic acid (mg) & 0.235 & 0.213 & 0.197 & 0.334 & 0.300 \\
\hline Vitamin $\mathrm{B}_{6}(\mathrm{mg})$ & 0.329 & 0.112 & 0.119 & 0.4 & 0.113 \\
\hline Folate $(\mu \mathrm{g})$ & 24 & 18 & 43 & 20 & 6 \\
\hline Vitamin C (mg) & 13.8 & 47.8 & 36.4 & 8.7 & 2.0 \\
\hline Calcium (mg) & 24 & 13 & 11 & - & 35 \\
\hline Iron $(\mathrm{mg})$ & 0.23 & 0.29 & 0.16 & 0.26 & 0.37 \\
\hline Magnesium (mg) & 29 & 12 & 10 & 27 & 17 \\
\hline Manganese (mg) & 0.043 & 0.927 & 0.063 & 0.27 & 0.128 \\
\hline Phosphorous (mg) & 21 & 8 & 14 & 22 & 14 \\
\hline Potassium (mg) & 448 & 109 & 168 & 358 & 242 \\
\hline Sodium (mg) & 2 & 1 & 1 & 1 & 1 \\
\hline Zinc (mg) & 0.13 & 0.12 & 0.09 & 0.15 & 0.15 \\
\hline Water $(\mathrm{g})$ & 73.5 & 86.00 & 81.81 & 74.91 & 79.06 \\
\hline
\end{tabular}

Source: Adapted from United States Department of Agriculture (2016, May) report.

\subsection{Jackfruit seed}

Jackfruit seeds are underutilized and less acknowledged by people, but they have considerable nutritional benefits and constitute about $10 \%$ to $15 \%$ of the fruit weight (Hossain, 2014). In many parts of South India, the seeds are collected from the ripe fruit, dried in sunlight and stored adequately for use in the rainy season. Due to the difficulties encountered during processing and storage, massive amounts of seeds are annually wasted.

Due to perishable nature, the seeds are usually discarded as waste, but when stored in a cool, moist environment, they have a shelf-life of about one month. To extend the shelf-life, the roasted seeds can be made into powders and used to add value to different products. Jackfruit seed powder is used as an alternative flour in bakery and confectionary products by blending it with wheat flour and other low-cost flours (Hossain, 
2014). In certain parts of India, the seeds are consumed by boiling or roasting them or used to supplement potato (Banerjee \& Datta, 2015).

Malnutrition is one of the major problems in India due to inadequate protein intake. Jackfruit seeds could be used as an economic alternative protein source to tackle the malnutrition (Roy Chowdhury et al., 2012). The demand for jackfruit seeds has been increased due to increased consumer awareness regarding the dietdisease relationship. It is believed to be a potent functional food ingredient since it imparts additional physiological benefits in addition to basic nutrition.

\subsection{Nutritional properties of jackfruit seeds}

The nutritional and antioxidant properties of jackfruit seeds have not yet been fully explored. Jackfruit seed provide an ample supply of protein, fiber, and starch. Jackfruit is also a rich source of many minerals such as N, P, K, Ca, Mg, S, Zn, Cu, etc (Maurya \& Mogra, 2016). Figure 1 shows the FTIR spectrum of jackfruit seed flour. The absorption bands and the wavenumber (cm-1) of the dominant peaks obtained from the absorption spectrum are for amines, amides, and amino acids, which indicate the presence of protein. Other absorption bands suggest the presence of biomolecules such as carbohydrates, polysaccharides, and lipids. The aromatic compounds indicate the existence of flavonoids and jackfruit seeds contain sulphur and its derivatives, which are responsible for its anti-microbial action.

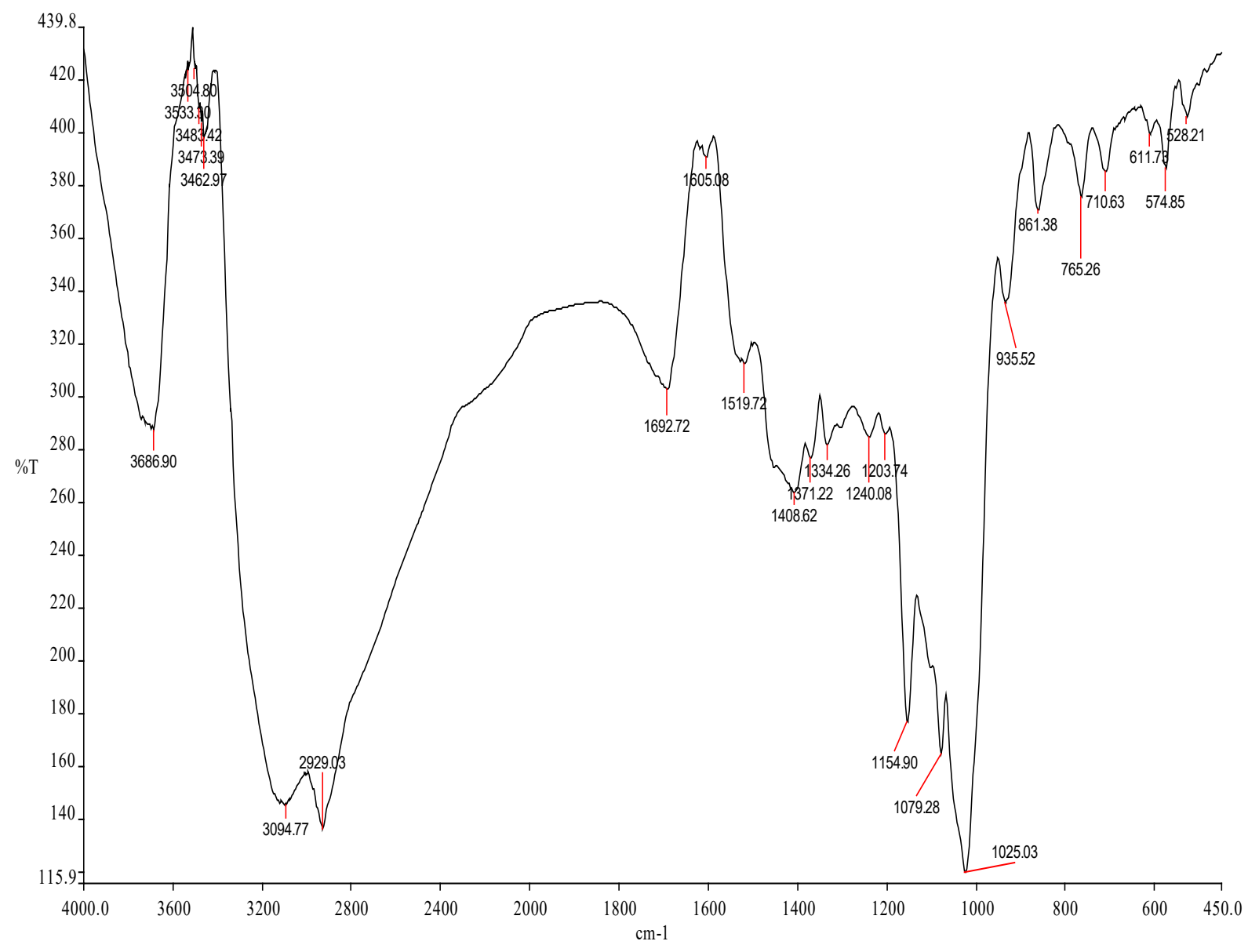

Figure 1. Wave number (cm-1) of dominant peaks obtained from the FT-IR absorption spectrum of jackfruit seed flour. Adapted from Gat \& Ananthanarayan (2015a). 


\subsection{Health benefits of jackfruit seeds}

Figure 2 shows the health benefits and functional properties of jackfruit seeds for the human body. The phytonutrients such as lignans, saponins, and isoflavones present in the seeds, plays beneficial role in human health (Noor, 2014). The addition of the jackfruit seed flour to deep-fried products results in a reduction in fat absorption up to a certain limit (Butool \& Butool, 2015). The seeds are rich in dietary fiber and B-complex vitamins and due to their high fiber content, they help lower the risk of heart disease, prevent constipation and promote weight loss. Jackfruit seeds also contain resistant starch, which controls blood sugar and keeps the gut healthy. Jackfruit seeds possess anti-microbial activity, which prevents foodborne diseases (Maurya \& Mogra, 2016) and the seeds contain an important lectin known as jacalin, used as a tool to evaluate the immune system of an HIV infected person. In China the seeds are known to be beneficial in overcoming the toxicity due to alcohol and likewise, in India, the seeds are a crucial component of an antidote produced for heavy drinkers (Butool \& Butool, 2015).

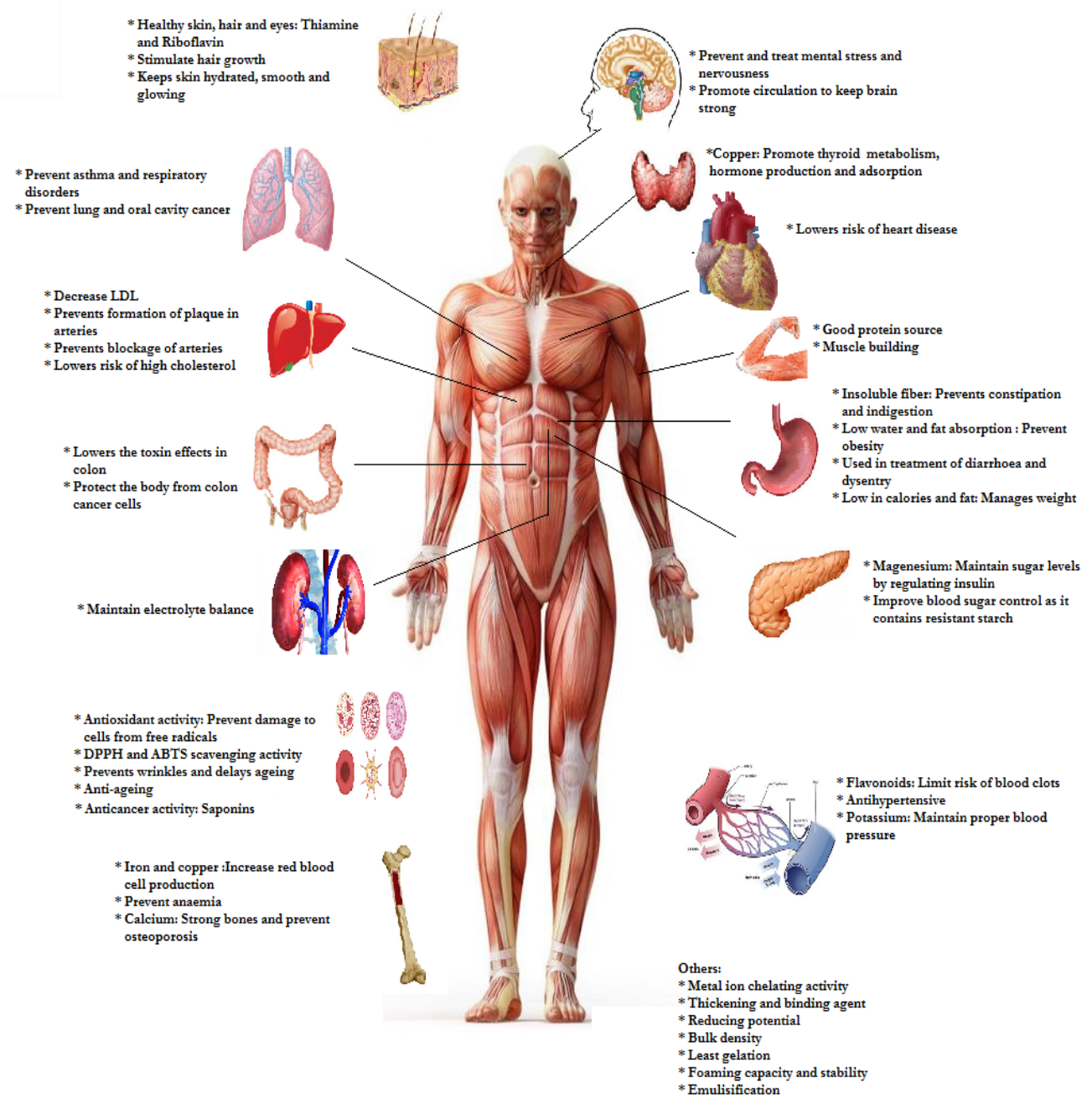

Figure 2. Health benefits and functional properties of jackfruit seed on the human body (Prakash et al., 2009). 
The seeds contain an abundance of magnesium which plays a vital role in lowering the blood pressure and maintaining bone health since it aids in calcium absorption and hence helps to strengthen the bones (Maurya \& Mogra, 2016). Furthermore, the seeds are rich in highly soluble protein resulting in the prevention and treatment of mental stress and anxiety. The seeds have low water and fat-absorption capacities, which helps in prevention of obesity.

\section{Value-added products prepared by incorporating jackfruit seed flour}

Value addition means the modification of a food commodity so as to enhance its value. This can be done by incorporating a new ingredient, using food processing technology or by changing the product packaging resulting in products that are far more appealing and usable. A few examples of value-added products are breakfast cereals, jams, ice creams, juices, yogurts, cheeses, pickles, concentrates, sauces, ketchup, extruded snacks, etc. Value addition requires creative ideas, a business understanding, and market demographics. Jackfruit seeds have been successfully used in the production of certain value-added products, some of which are represented in Table 2 (bakery products), Table 3 (extruded products) and Table 4 (other products).

\subsection{Bakery products}

The bakery industry is amongst the fastest growing organized food industries in India. Baked products are increasingly gaining popularity since they are convenient, readily available in diverse tastes and textural profiles, less expensive and possess high nutritive value. The chief advantage offered by bakery product is the ease with which they can be fortified with functional ingredients. Therefore, bakery products are an efficacious medium to deliver potent ingredients with health benefits to consumers. Recent studies have indicated that various bakery products such as biscuits (Islam et al., 2015), cookies, bread (Tulyathan et al., 2002), cake (Arpit \& John, 2015), muffins (Siti Faridah \& Noor Aziah, 2012) etc. have been formulated by supplementation with different levels of jackfruit seed flour (Table 2).

Table 2. Baked products prepared by jackfruit seed fortification in different forms and at different concentrations.

\begin{tabular}{|c|c|c|c|}
\hline Product name & $\begin{array}{c}\text { Amount of } \\
\text { supplementation (\%) }\end{array}$ & Outcome & Reference \\
\hline Bread & 5 & $\begin{array}{l}\text { High protein and carbohydrate content, } \\
\text { good water and oil absorption ability }\end{array}$ & Tulyathan et al. (2002) \\
\hline Bread & 25 & Increased crude fiber content & Butool \& Butool (2015) \\
\hline Bread & 25 & $\begin{array}{l}\text { Nutritionally higher carbohydrate, fat, } \\
\text { protein, and crude fiber content }\end{array}$ & Hossain (2014) \\
\hline Biscuit & 20 & $\begin{array}{l}\text { Good water and oil absorption capacity, } \\
\text { swelling power, percent solubility, flour } \\
\text { dispersibility and viscosity }\end{array}$ & Butool \& Butool (2015) \\
\hline Biscuit & $10-40$ & $\begin{array}{l}\text { Moisture, fat, crude fiber and ash content } \\
\text { increased }\end{array}$ & Islam et al. (2015) \\
\hline Cake & $5-15$ & $\begin{array}{l}\text { Increase in protein and reduction in fat } \\
\text { content }\end{array}$ & Arpit \& John (2015) \\
\hline Chocolate cake & $5-15$ & $\begin{array}{l}\text { Improved dietary fiber and anti-oxidant } \\
\text { activity }\end{array}$ & David (2016) \\
\hline Composite cake & $10-30$ & $\begin{array}{l}\text { Better crumb, texture and nutritional } \\
\text { characteristics }\end{array}$ & Khan et al. (2016) \\
\hline Muffins & $10-20$ & $\begin{array}{l}\text { Specific gravity increased and viscosity } \\
\text { decreased }\end{array}$ & $\begin{array}{l}\text { Siti Faridah \& Noor Aziah } \\
\text { (2012) }\end{array}$ \\
\hline
\end{tabular}

\subsubsection{Effect of addition of jackfruit seed flour on different properties of baked products}

The addition of jackfruit seed flour to numerous baked and cereal products enhanced their overall nutritional quality. Arpit \& John (2015) carried out a study on the effect of varying levels of supplementation of jackfruit seed flour on the quality parameters of chocolate cake by mixing wheat flour and jackfruit seed 
flour in different proportions. The incorporation of $10 \mathrm{~g}$ jackfruit seed flour per $100 \mathrm{~g}$ of wheat flour used to prepare chocolate cake, resulted in increase in the protein and ash contents and a decrease in the fat content. The incorporation of jackfruit seed flour in biscuits resulted in larger amounts of ash and crude fiber. A high ash content corresponds to the amount of mineral matter present in the flour. Since jackfruit seeds are rich in crude fiber, an increase in crude fiber was found in the biscuits, but the incorporation also resulted in losses in the protein and carbohydrate contents of the biscuits. Bread made with the incorporation of jackfruit seed flour showed a higher crude fiber content, whereas baked products are normally insufficient in dietary fiber (Islam et al., 2015).

A sensory evaluation refers to the measurement, analysis, and interpretation of responses to food commodities as perceived by the auditory, visual, olfactory, tactile and gustatory senses. It can be regarded as a scientific discipline that examines distinct attributes of a food component or product by observing alikeness and differences amongst a variety of commodities. The color of bread made with $25 \%$ substitution of jackfruit seed flour was the same as that of the control sample, but the addition of more jackfruit seed flour led to a change in color from light brown to dark brown. Similarly, in the case of flavor, both the control sample and the sample with $25 \%$ seed flour were more acceptable. The tastes of the control sample and of that supplemented with $25 \%$ jackfruit seed flour were similar and the texture of the bread with $25 \%$ seed flour was more preferred (Hossain, 2014). Biscuits and bread made with the incorporation of less than 30\% jackfruit seed flour showed good overall acceptability, but further increases in the jackfruit seed flour concentration decreased the overall acceptability of the bread and biscuits (Butool \& Butool, 2015).

\subsection{Extruded products}

In many food processing industries, extrusion cooking technology plays a pivotal role as continuous cooking, mixing, shearing and form-making technique, and the main reasons for customer acceptance of extruded foods are the convenience, value, appearance and texture (Gat \& Ananthanarayan, 2015a). This technology is mainly used in the production of breakfast cereals, snacks, snack pellets, crispy flatbread, pre-cooked flours, and cereal-based baby foods.

\subsubsection{Effect of addition of jackfruit seed flour on different properties of extruded products}

The effect of incorporating jackfruit seed flour on the moisture content of pasta was found to be insignificant $(p \leq 0.05)$ but the protein and ash content increased (Abraham \& Jayamuthunagai, 2014). In comparison with the control sample, noodles fortified with jackfruit seed flour showed increases in the protein, ash, fat and crude fiber contents and reduced carbohydrate content (Nandkule et al., 2015).

The nutrimental and nutraceutical properties of extrudates were improved by the incorporation of jackfruit seed flour into the rice. The nutrimental composition of the extrudate was improved at a concentration of 70:30 (rice:jfsf) with a barrel temperature of $180^{\circ} \mathrm{C}$ and a screw speed of $300 \mathrm{rpm}$. Increases in the total phenolic and flavonoid contents were reported with a decrease in the barrel temperature, and the extrudate obtained at $180{ }^{\circ} \mathrm{C}$ and $300 \mathrm{rpm}$ exhibited the highest antioxidant and reducing potential (Gat \& Ananthanarayan, 2015b).

Table 3 summarizes some extruded products prepared by fortification with jackfruit seed flour. The addition of different proportions of jackfruit seed flour to control pasta increased the nutrient content but showed similar cooking and rheological qualities. Kumari et al. (2015) developed jackfruit seed flour-based noodles which ensured the presence of the functional properties. The addition of 10 and $20 \%$ jackfruit seed flour in the development of noodles with a feeder speed of $16 \mathrm{rpm}$ and drying temperature of $60{ }^{\circ} \mathrm{C}$ resulted in lower energy and carbohydrate contents but higher protein, fiber, and mineral contents and better sensory quality. Noodles extruded with $20 \%$ jackfruit seed flour showed higher yields and lower cooking times, as reported by Kumari \& Divakar (2017), and the color of the pasta changed with the addition of the jackfruit 
seed flour. The flavor of the jackfruit seed was easily recognizable in pasta with the addition of $15 \%$ and $20 \%$ seed flour, and it was suggested that the firmness of the pasta also increased with the addition of the seed flour.

Table 3. Extruded products prepared by jackfruit seed fortification in different forms and at different concentrations.

\begin{tabular}{|c|c|c|c|}
\hline Product name & $\begin{array}{c}\text { Amount of } \\
\text { supplementation (\%) }\end{array}$ & Outcome & Reference \\
\hline Expanded snacks & $10-40$ & $\begin{array}{l}\text { Increase in nutritional and } \\
\text { phytochemical properties }\end{array}$ & $\begin{array}{l}\text { Gat \& Ananthanarayan } \\
(2015 b)\end{array}$ \\
\hline Pasta & 10 & Increased nutrient content & $\begin{array}{c}\text { Abraham \& } \\
\text { Jayamuthunagai (2014) }\end{array}$ \\
\hline Fortified noodles & 5 & $\begin{array}{l}\text { Higher protein, fat, fiber, ash content and } \\
\text { better organoleptic properties }\end{array}$ & Nandkule et al. (2015) \\
\hline Noodles & $10-20$ & $\begin{array}{c}\text { Higher yield ratio and lower cooking } \\
\text { time }\end{array}$ & Kumari \& Divakar (2017) \\
\hline
\end{tabular}

\subsection{Traditional products}

A snack is a portion smaller than a full-fledged meal and is typically consumed between meals. Snacks deliver significantly fewer calories than those provided by a regular meal and processed snack foods are convenient to use and possess longer shelf-life. The processed food industry has a continuously increasing interest in developing novel products to attract consumers. Traditional snacks and other products such as Karasev, Jamun, cereal bars, chocolate milkshake and Chapatti supplemented with jackfruit seed flour are mentioned in Table 4 . Cereal bars made with $30 \%$ and $40 \%$ jackfruit seed meal showed high fiber contents, better sensory characteristics and nutritive values similar to those of other bars available on the market (Santos et al., 2011). The development of a cereal bar with 15\% jackfruit seed flour maintained the hardness and crispness when compared with commercially available cereal bars without the addition of this exotic fruit (Torres et al., 2011) and the protein content of the snack bar increased when jackfruit seed flour was incorporated (Meethal et al., 2017). Jackfruit seed flour, bengal gram flour, and wholemeal wheat flour were blended in different combinations to produce chapatis, the addition of $10 \%$ jackfruit seed flour showed the best overall acceptance (Sultana et al., 2014).

Table 4. Other products prepared by jackfruit seed fortification in different forms and at different concentrations.

\begin{tabular}{cccc}
\hline Product name & $\begin{array}{c}\text { Amount of } \\
\text { supplementation (\%) }\end{array}$ & Outcome & Reference \\
\hline Karasev and Jamun & 25 and 50 & Decreased fat absorption capacity & $\begin{array}{c}\text { Sri Rajarajeshwari \& } \\
\text { Prakash (1999) }\end{array}$ \\
Cereal bar & 30 and 40 & High fiber content, better sensorial & Santos et al. (2011) \\
Cereal bar & 15 & Preserved hardness and crispness & Torres et al. (2011) \\
Snack bar & $35-45$ & Increased protein content & Meethal et al. (2017) \\
\hline
\end{tabular}

\subsubsection{Effect of addition of jackfruit seed flour on different properties of traditional products}

Recent studies concerning the nutritional properties of three varieties of jackfruit seed flour showed that all the seed varieties contained good amounts of protein, ranging from $13 \%$ to $18 \%$ and that the crude fiber content varied between $1.56 \%$ to $2.60 \%$ (Abedin et al., 2012). Mukprasirt \& Sajjaanantakul (2004) reported that the starch obtained from jackfruit seed has a higher amylose content which could be used as a substitute for modified starch.

Various researchers have recognized jackfruit seed as a novel functional ingredient with a desirable nutraceutical potential due to its high content of phytonutrients (Conforti \& Cachaper, 2009). Gupta et al. (2011) found a high amount of saponins i.e., $6.32 \mathrm{~g} / 100 \mathrm{~g}$ on carrying out a phytochemical analysis of 
jackfruit seeds. The antioxidant activity was determined using free radical scavenging, metal chelating, ferric reducing antioxidant power and reducing power assays, and it was concluded that jackfruit seed exhibited strong antioxidant properties and a moderate amount of phytochemicals. Studies on the total phenolic compounds, flavonoids, reducing power and antioxidant activity of four different extracts of jackfruit seed showed that plants containing phenols and flavonoids exhibit strong antioxidant potentials. These results indicate the use of jackfruit seed extract as a good functional medicine and pharmaceutical plant-based product due to its high flavonoid (0.86 to 4.05) content and reducing potential (9.56 to 13.12) (Shanmugapriya et al., 2011).

The jackfruit seed protein has a high surface viscosity property, so more air is entrapped for a longer time. It has been reported that jackfruit seed flour has low emulsifying capacity when compared to wheat flour. The study conducted by Roy Chowdhury et al. (2012) indicated that the jackfruit seed flour protein was less soluble, but the solubility increased with increasing $\mathrm{pH}$ value.

\section{Conclusion}

Studies have suggested a significant increase in the nutritional content of jackfruit-fortified products in terms of the ash, protein, dietary fiber and phytochemical contents. The incorporation of jackfruit seed flour at the optimum concentration aided in improving the physicochemical, textural, color and sensory properties of various products. Furthermore, the review discussed the effect of adding jackfruit seed flour on the different attributes of traditional products. Additional experimentation is required to develop economical and efficient practices for the production of value-added products containing jackfruit seed flour.

\section{References}

Abedin, M. S., Nuruddin, M. M., Ahmed, K. U., \& Hossain, A. (2012). Nutritive compositions of locally available jackfruit seeds (Artocarpus heterophyllus) in Bangladesh. International Journal of Biosciences, 2, 1-7.

Abraham, A., \& Jayamuthunagai, J. (2014). An analytical study on jackfruit seed flour and its incorporation in pasta. Research Journal of Pharmaceutical, Biological and Chemical Sciences, 5(2), 1597-1610.

Arpit, S., \& John, D. (2015). Effects of different levels of jackfruit seed flour on the quality characteristics of chocolate cake. Research Journal of Agriculture and Forestry Sciences, 3(11), 6-9.

Banerjee, S., \& Datta, S. (2015). Effect of dry heat treated jackfruit seed powder on growth of experimental animals. IOSR Journal of Pharmacy and Biological Sciences, 10, 42-46.

Butool, S., \& Butool, M. (2015). Nutritional quality on value addition to jack fruit seed flour. International Journal of Scientific Research, 4, 2406-2411.

Conforti, F. D., \& Cachaper, K. F. (2009). Effects of selected antioxidants on physical and sensory characteristics of yeast bread containing flaxseed meal. International Journal of Consumer Studies, 33(1), 89-93. http://dx.doi.org/10.1111/j.14706431.2008.00729.x

David, J. (2016). Antioxidant properties of fiber rich dietetic chocolate cake developed by jackfruit (Artocarpus heterophyllus L. ). Seed Flour, 2, 132-135. http://dx.doi.org/10.18178/ijfe.2.2.132-135

Gat, Y., \& Ananthanarayan, L. (2015a). Effect of extrusion process parameters and pregelatinized rice flour on physicochemical properties of ready-to-eat expanded snacks. Journal of Food Science and Technology, 52(5), 2634-2645. PMid:25892761. http://dx.doi.org/10.1007/s13197-014-1378-7

Gat, Y., \& Ananthanarayan, L. (2015b). Physicochemical, phytochemical and nutritional impact of fortified cereal-based extrudate snacks. Nutrafoods, 14(3), 141-149. http://dx.doi.org/10.1007/s13749-015-0036-7

Gupta, D., Mann, S., Sood, A., \& Gupta, R. K. (2011). Phytochemical, nutritional and antioxidant activity evaluation of seeds of jackfruit (Artocarpous heterolphyllus Lam.). International Journal of Pharma and Bio Sciences, 2, 336-345.

Hossain, M. T. (2014). Development and quality evaluation of bread supplemented with jackfruit seed flour. International Journal of Nutrition and Food Sciences, 3(5), 484. http://dx.doi.org/10.11648/j.jinfs.20140305.28

Islam, S., Begum, R., \& Khatun, M. (2015). A study on nutritional and functional properties analysis of jackfruit seed flour and value addition to biscuits. International Journal of Engineering Research \& Technology, 4(12), 139-147.

Khan, S. A., Saqib, M. N., \& Alim, M. A. (2016). Evaluation of quality characteristics of composite cake prepared from mixed jackfruit seed flour and wheat flour. Journal of the Bangladesh Agricultural University, 14(2), 219-227. http://dx.doi.org/10.3329/jbau.v14i2.32697 
Kumari, V. S., \& Divakar, S. (2017). Quality analysis of raw jackfruit based noodles. Asian Journal of Dairy and Food Research, 36(01), 45-51. http://dx.doi.org/10.18805/ajdfr.v36i01.7458

Kumari, V., Divakar, S., Ukkruu, M., \& Nandini, P. V. (2015). Development of raw jackfruit based noodles. Food Science Research Journal, 6(2), 326-332. http://dx.doi.org/10.15740/HAS/FSRJ/6.2/326-332

Maurya, P., \& Mogra, R. (2016). Assessment of consumption practices of jackfruit (Artocarpus heterophyllus lam.) seeds in villages of Jalalpur block district Ambedarnagar (U.P.) India. Remarking, 2, 73-75.

Meethal, S. M., Kaur, N., Singh, J., \& Gat, Y. (2017). Effect of addition of jackfruit seed flour on nutrimental, phytochemical and sensory properties of snack bar. Current Research in Nutrition and Food Science, 5(2), 154-158. http://dx.doi.org/10.12944/CRNFSJ.5.2.12

Mukprasirt, A., \& Sajjaanantakul, K. (2004). Physico-chemical properties of flour and starch from jackfruit seeds (Artocarpus heterophyllus Lam.) compared with modified starches. International Journal of Food Science \& Technology, 39(3), 271-276. http://dx.doi.org/10.1111/j.1365-2621.2004.00781.x

Nandkule, V. D., Masih, D., Sonkar, C., \& Patil, D. D. (2015). Development and quality evaluation of jackfruit seed and soy flour noodles. International Journal of Science, Engineering and Technology, 3, 802-806.

Noor, F. (2014). Physicochemical properties of flour and extraction of starch from jackfruit seed. International Journal of Nutrition and Food Sciences, 3(4), 347. http://dx.doi.org/10.11648/j.ijnfs.20140304.27

Prakash, O., Kumar, R., Mishra, A., \& Gupta, R. (2009). Artocarpus heterophyllus (Jackfruit): An overview. Pharmacognosy Reviews, 3, 353-358.

Roy Chowdhury, A., Bhattacharyya, A. K., \& Chattopadhyay, P. (2012). Study on functional properties of raw and blended jackfruit seed flour (a non-conventional source) for food application. Indian Journal of Natural Products and Resources, 3, 347353.

Santos, C. T., Bonomo, R. F., Da Costa llhéu Fontan, R., Bonomo, P., Veloso, C. M., \& Fontan, G. C. R. (2011). Characterization and sensorial evaluation of cereal bars with jackfruit. Acta Scientiarum. Technology, 33, 81-85. http://dx.doi.org/10.4025/actascitechnol.v33i1.6425

Shanmugapriya, K., Saravana, P. S., Payal, H., Peer Mohammed, S., \& Binnie, W. (2011). Antioxidant activity, total phenolic and flavonoid contents of Artocarpus heterophyllus and Manilkara zapota seeds and its reduction potential. International Journal of Pharmacy and Pharmaceutical Sciences, 3, 256-260.

Siti Faridah, M. A., \& Noor Aziah, A. A. (2012). Development of reduced calorie chocolate cake with jackfruit seed (Artocarpus heterophyllus Lam.) flour and polydextrose using Response Surface Methodology (RSM). International Food Research Journal, 19, 515-519.

Sri Rajarajeshwari, H., \& Prakash, J. (1999). Jack fruit seeds: Composition, functionality and use in product formulation. The Indian Journal of Nutrition and Dietetics, 36, 312-319.

Sultana, A., Tanver Rahman, M. R., Islam, M., Rahman, M., \& Alim, M. A. (2014). Evaluation of quality of chapaties enriched with jackfruit seed flour and bengal gram flour. IOSR Journal of Environmental Science, Toxicology and Food Technology, 8(5), 73-78. http://dx.doi.org/10.9790/2402-08537378

Torres, E. R., Santana, E., Felix, R., Santana, D., \& Cordeiro, J. (2011). Cereal bar development using exotic fruit. In 11th International Congress on Engineering and Food: Food Process Engineering in a Changing World. Athens: ICEF.

Tulyathan, V., Tananuwong, K., Songjinda, P., \& Jaiboon, N. (2002). Some physicochemical properties of jackfruit (Artocarpus heterophyllus Lam) seed flour and starch. ScienceAsia, 28(1), 37-41. http://dx.doi.org/10.2306/scienceasia15131874.2002.28.037

United States Department of Agriculture - USDA. Natural Resources Conservation Service - NRCS. (2016). The PLANTS Database. Greensboro: National Plant Data Team. 